\title{
The many truths of Bennelong's tragedy
}

\author{
Emma Dortins
}

In life, Bennelong was by no means the only mediator between the Aboriginal peoples of the Sydney region and the colonists, but across the latter half of the twentieth century, he took on a singular role as chief intermediary between the present and the past. It is through Bennelong's story that many Australians feel they know something of the great encounter between the invading Europeans and the Australian Aborigines, and something of the truth of its outcomes. Bennelong, as Lyndall Ryan has shown of Trucanini, is surrounded by dense and various 'storywork' which has made him 'a resilient figure in debates about the future of Australian Aboriginals today ... [and the focus of] a struggle for ownership and possession of the colonial past'. ${ }^{1}$ While some of this storywork has been undertaken in scholarly articles and monographs, much of it can be characterised as a 'form of social knowledge' that has taken place without historians: ${ }^{2}$ novels, children's books, political and promotional material and the 'user generated content' of the internet. While stories of Bennelong are profuse, however, they are not nearly as 'promiscuous' as I had expected. ${ }^{3}$ In most popular, official and even academic accounts published in the past seven decades, Bennelong dies broken and rejected as a result of his exhilarating but corrupting involvement with the colonists. Storytellers have demonstrated a loyalty to Bennelong's tragedy or failure across significant shifts in Australian and Aboriginal historiography. This paper begins to explore some of the variations on Bennelong's tragic story, attempts to separate out some of its layers of plausibility, and to enquire into the possible meanings of this repeated reinscription of cross-cultural tragedy.

\section{I}

The modern originator of Bennelong's tragedy was perhaps Eleanor Dark, in her enormously influential novel of 1941, The Timeless Land. ${ }^{4}$ Dark sought to tell,

1 Ryan 1997: 154

2 Healy 2002: 124.

3 'Promiscuous' is one of Keith Jenkins' designations for a relativist past which is content to associate itself with any version of history, to suit the requirements of the present, Curthoys and Docker 2006: 6.

4 The trilogy of which it is the first volume has been in print in Australia for most of the 60 years since its publication. In the 1950s it was set as a school text and, in 1980, turned into a miniseries for $\mathrm{ABC}$ television. The novel also took Australian history to an overseas audience, being a bestseller in the United States in 1941, as well as topping the Times Literary Supplement Christmas Fiction List in the United Kingdom, and was later translated into German and 
for the first time, 'a story of the white settlement partly from the black man's point of view' ${ }^{\prime}{ }^{5}$ Drafts featured a long prologue depicting Aboriginal life before the arrival of the First Fleet. But the novel was immense, and with war looming, Dark felt the need to focus the story more intensely on a 'clash of values' within white society. On publisher William Collins' suggestion, she funneled her prologue into a much terser tableau focused throughout on Bennelong, one of her chief Aboriginal protagonists. ${ }^{6}$ It is thus Bennelong who both begins and ends the story, transformed from a sweet child trailing after his fictional father, Wunbula, in the first paragraphs, to the broken adult of the Epilogue. In the final scene, Bennelong revisits the rock platform where Wunbula had made a carving of Cook's ship, and where father and son had looked out to sea together. He is drunk and angry. When he stumbles across the carving, he throws himself down and starts to vandalise it until he collapses, overwhelmed by alcohol and a sense of loss:

the ground lurched, and the whole world spun. As he pitched forward across the rock a bit of broken bottle gashed his arm, and blood ran into the defaced grooves of Wunbula's drawing. Bennilong lay still, snoring heavily, while the merciful, swift twilight of his land crept up about him to cover his defeat. The End. ${ }^{7}$

Dark's Bennelong had been drawn by a 'thread of destiny' into the 'alien world' of the white men. ${ }^{8}$ His initial anger at being kidnapped had subsided as he found himself wanting to be like these fascinating strangers. But he was destined to fail: Dark's Aborigines, though self-sufficient and creative within their own culture, were nevertheless conceived through a social Darwinism still pervasive in the interwar period, as the 'monkey-like' 'children of the human family', hard-wired to an unchanging existence. ${ }^{9}$ With this proviso, his rush to cultural exchange was Icarus-like. When published, Dark's novel was both celebrated and criticised as being almost closer to history than to fiction, providing, despite the late shift in focus, an unprecedented view of cross-cultural relations in the colony..$^{10}$ Manning Clark said that his own History of Australia was inspired by Dark's novels, ${ }^{11}$ and although much less interested in an Aboriginal perspective in this history, he concurred with Dark on Bennelong's unenviable fate, saying

Swedish. When published, it was seen to be almost more a work of history than of fiction. (Barbara Brooks, Introduction in Dark 2002: vi-vii; Humphrey McQueen, Introduction in Dark 2002: xix, xxii; Brooks 1998: 357-359.)

5 Brooks 1998: 350.

6 Brooks 1998: 347-50; Wyndham 2007: 180-181.

7 Dark 1980: 539-544.

8 Dark 1980: 49.

9 Dark's Barrangaroo, for example, senses a danger in the British arrival but cannot apprehend it, as 'the passing centuries, going quietly over the heads of her ancestors, had evolved in their brains no machinery for the understanding of Change', Dark 1980: 151, 179-180, 406; Reynolds 2005: 67-72; Brooks 1998: 364-365.

10 Brooks 1998: 357-359.

11 Brooks 1998: 427. 
Bennelong: 'disgusted his civilisers and became an exile from his own people, and rushed headlong to his dissolution as a man without the eye of pity from the former, or affection from the latter' ${ }^{12}$

WEH Stanner, in his Boyer Lectures of 1968, found a slow revolution underway in his contemporary Australia, in which the 'Aboriginal question' was rising to the surface in social and political discussions. ${ }^{13}$ A new history, entirely different from what had gone before, would be necessary, acknowledging the Aboriginal side to the story. ${ }^{14}$ This new history would not necessarily hold a more sanguine view of Bennelong, however. When Stanner asked his listeners to imagine Aboriginal men and women of 'outstanding ... character and personality', he made a quick qualification: 'I am not thinking of mercurial upstarts like Bennelong'. ${ }^{15}$ In another influential article, he described Bennelong as a 'volatile egotist, mainly interested in love and war; a tease, a flirt and very soon a wine-bibber; a trickster and eventually a bit of a turncoat'. ${ }^{16}$ Stanner felt that the Aboriginal-British relations developed around the Sydney colony in 1788-1790 had broadly set the pattern for relations across the continent, and credited the readily-pleased and soon 'mendicant' Bennelong with being at the head of a chain reaction 'which ... forced one tribe after another into some sort of dependency on Europeans' ${ }^{17}$

Throughout the 1960s, the iconic Sydney Opera House was under construction on Bennelong Point, where the small brick house built on Bennelong's request, and Phillip's orders, had formerly stood. When the Opera House was opened in 1973, Bennelong was accorded a level of interest perhaps unequalled since the 1790s. He appeared in the opening ceremony in the shape of Aboriginal actor Ben Blakeney, who delivered an oration from the topmost peak of the tallest shell. ${ }^{18}$ Stanner had set up a strong link between Bennelong's story and the 'Aboriginal question'. Where it had previously been possible to tell Bennelong's story simply as the story of a 'remarkable character' who had fascinated the colonists, been to England and back, and died in a tribal fight, ${ }^{19}$ now it was increasingly invested with explanatory power: following the 1967 Referendum, and as the muchtelevised tent embassy was removed from the lawns of Parliament House for the second time, biographers of Bennelong felt a responsibility to engage with

12 Clark 1962: 145

13 Stanner 1968: 7, 26.

14 Stanner 1968: 25-26.

15 Stanner 1968: 45.

16 Stanner 1977: 19-20.

17 Stanner 1968: 7-11, 1977: 19-20.

18 Ziegler 1974. The oration reminded listeners that this place had been an Aboriginal place, of 'the dreamtime - of spirit heroes, and of earth's creation' and ceremony, and suggested that the place was presided over by a laughing, singing spirit-presence.

19 See for example McGuanne 1901, and the adaptation of McGuanne's story for the Benelong Bugle, a periodical circulating amongst the workers on the Opera House site from 1962, in which Bennelong is an action figure dashing in and out of the settlement, who returns from England 'a drunken quarrelsome swaggerer, eventually went bush, and in 1831 [sic] was killed in a tribal fight'. Benelong Bugle, 1962, vol 1: 16-17. 
the broader 'Aboriginal question'. In a biography commissioned by the Royal Australian Historical Society to mark the Opera House opening, John Kenny found Bennelong instructive as:

the first of his people to be a well-documented example of their social incompatibility with their conquerors - an incompatibility which has persisted, afflicting the conquerors' conscience and mocking their compassion and ingenuity. ${ }^{20}$

Founding chairman of the Council of Aboriginal Affairs, HC Coombs, provided the foreword to Kenny's book, and agreed that the relationship between Phillip and Bennelong was 'disturbingly pertinent to our respective positions to-day ... a sombre episode which, with minor variations, has been replayed countless times throughout Australia' ${ }^{21}$ In this account, Bennelong again suffers not so much from loss of land and resources, from upheaval in the political, social and economic world of the Eora, or from loss of family and allies through smallpox; he is above all the victim of 'an ignorant and futile attempt to civilise him which made him a pathetic victim of confusion of his own and the founders' cultures' ${ }^{22}$ If Bennelong was at times more a pathetic failure than a tragic figure, the notion that his story was predictive of Aboriginal stories across the continent lent the matter a gravity of magnitude which invited noble sentiments.

A second biography celebrating the Opera House opening, by journalist Isadore Brodsky, also claimed relevance to the 'Aboriginal question', seeking to do Bennelong's 'memory some justice', and make a 'contribution to [the Aborigines'] emancipation and proper recognition in Australian life'.$^{23}$ Brodsky's loyalty to the cultural hierarchies of an earlier age, however, defeated his ostensible will to justice in the present. Like Dark, Brodsky understood Bennelong to be a 'Stone Age' man, caught between eternal childhood and manhood on the evolutionary scale. ${ }^{24}$ Brodsky sent Bennelong on a vertical trajectory: a dizzying rise towards 'civilisation' as Phillip and his officers endeavoured to 'enlighten and to refine' him, and then a fall as he failed to maintain its standards. ${ }^{25}$ The clear pinnacle of his career was his putative visit to King George III. ${ }^{26}$ But not long after his return from England 'civilisation fell off him like an unwanted cloak'. Brodsky's Bennelong first took a 'step backwards in his civilized progress' and then tumbled into an unstoppable 'downward rush' of 'progressive degradation' ${ }^{27}$ As in Dark's narrative, Bennelong's failure is prefigured in traditional tragic fashion: from his first taste of alcohol we know that this substance will lead to his ruin. ${ }^{28}$

20 Kenny 1973: 5.

21 HC Coombs in Kenny 1973: 1.

22 Kenny 1973: 5.

23 Brodsky 1973: 16, 17.

24 Brodsky 1973: 76.

25 Brodsky 1973: 13, 26-28, 75.

26 Brodsky 1973: 20, 65 and plate opposite.

27 Brodsky 1973: 67, 69, 70, 78.

28 Brodsky 1973: 27. 
In a lecture celebrating the discovery of the First Government House Site in 1984, archaeologist John Mulvaney agreed with Stanner's assessment of Bennelong's dubious legacy: 'a behavioural pattern which has been termed "intelligent parasitism", but which simply adapted to the whims of European patrons' ${ }^{29}$ Inspired by a 'resistance' historiography that invoked the power and drama of the Vietnamese anti-colonial struggles, and an Aboriginal activism characterised by violent confrontations with the police and 'the belligerent rhetoric of the Black Power movement', ${ }^{30}$ Mulvaney turned his listeners' attention to Pemulwuy as a man who would be 'most celebrated by his people around 1988 '. He doubted that Bennelong 'is much honoured today by his people' ${ }^{31}$ But Aboriginal thinkers did not necessarily cut Bennelong off as Mulvaney expected them to do. Eric Willmot, in his novel Pemulwuy, certainly depicted Bennelong as a 'loser'. But all his characters were losers (except, perhaps, the charismatic eponymous hero). Bennelong is simply the most spectacular loser, with Governor Hunter a close second. He is not, however, the pathetic victim of one culture crashing against another, like wave against cliff, as Kenny and others would have us believe. Rather, he plays hard at politics and he falls hard. ${ }^{32}$ Ann Curthoys observes that Australians love a 'good' loser, like the martyrs of Gallipoli, ${ }^{33}$ and Willmot's Bennelong gives his all for his cause, to gain and keep the initiative in dealings with the British, and knows when he has been trumped. ${ }^{34}$ In the bicentennial Encyclopaedia of the Nation, Charles Perkins similarly paid tribute to Bennelong as one of a group of Aboriginal leaders, leading 'a school of thought among the Eora people ... that the British arrival was an important event from which both people had much to gain' ${ }^{35}$ Perkins noted the different 'approaches' of Colbee and Pemulwuy, but he did not claim that these men maintained their integrity in a way that Bennelong did not. ${ }^{36}$

Much loved country singer and song-writerTed Egan, published TheAboriginals Songbook in time for the bicentenary, in which he depicted Bennelong as 'the first political victim' and a lost soul:

I couldn't help thinking that Benelong/Never again sang the eagle song/For he seemed just like a man whose spirit left him/Doomed was he forever more/He lost his way as he lost his law/And the white sea eagle sings its song alone. ${ }^{37}$

At the beginning of the new millennium, Egan's remained very much the dominant verdict on Bennelong. A recent children's book titled the final three chapters of Bennelong's story: 'A lonely man'; 'Rejecting tribal law'; and 'Drunkenness and

29 Mulvaney 1985: 14.

30 Reece 1987: 16-17.

31 Mulvaney 1985: 14.

32 Willmot 1987: 30, 54, 173, 219-220, 268-270.

33 Curthoys 2000: 23-25.

34 Willmot 1987: 192, for example.

35 Perkins 1988: 235.

36 Perkins 1988: 235.

37 Egan 1987: 36-37. 
death' ${ }^{38}$ The Sydney Opera House World Heritage Nomination (2006) concludes its brief consideration of the man: 'Bennelong dies in 1813, alienated from both Aboriginal and European cultures'. ${ }^{39}$ The Marrickville Council website finds him 'increasingly depressed, drunk, aggressive and vengeful' in the period leading up to his death. ${ }^{40}$ Inga Clendinnen, in her recent, close re-examination of social, political and cultural exchange in the first years of the colony, Dancing with Strangers, found Bennelong a complex and intelligent mediator. Clendinnen returned to colonial relationships hoping to recover the many-coloured and fragile optimism of first contact, and to see whether there were ever any other possibilities but cross-cultural failure. She found resounding failure there through Bennelong and wrote him a death almost as apostrophic as that wrought by Dark 65 years earlier. When Clendinnen's Bennelong returns from England, he is a virtual 'Englishman' who had 'decided to commit himself to the British account of things', ${ }^{41}$ yet he finds his influence with the colonists far less potent, he experiences terrible luck with women, and obliterates his disappointment with rum. She concludes:

Baneelon, with his anger and his anguish, simply drops from British notice. He did not die until 1813 ... Over the last years of his life Baneelon abandoned the British in his heart, as they had long abandoned him in the world. At fifty he fumed his way to an outcast's grave. He should have died earlier, in the days of hope. ${ }^{42}$

Clendinnen acknowledges that the last years of Bennelong's life are little known, but she is content to imply that they were characterised by a burning anger and a lonely exile from both Aboriginal and European society. ${ }^{43}$

Keith Smith's 2001 biography left off as Bennelong sailed for England. His justification at the time was that Bennelong's latter years were discontinuous with the diplomat's life he had traced to that point:

In this second part of his life, Bennelong was a changed man. He abandoned the white settlement, took to drink and was frequently wounded in payback battles ... That is another story. ${ }^{44}$

Perhaps he did not want to write a tragedy, but at that time felt that curtailing his narrative was the only way to avoid it. But as can be seen in Smith's article in the present volume, he is now able to marshal enough evidence to refute conclusively the claim that Bennelong died outcast from both Aboriginal and European society, and to set our musings on his relationships with the British much more firmly within his Eora kinship structures.

38 Sheppard 2005: 26-27.

39 Commonwealth of Australia 2006, Appendix 10D: 112. See also Wikipedia, 'Bennelong', updated 26 January 2009.

40 Marrickville Council, 'Cadigal Whangal' webpages.

41 Clendinnen 2003: 265.

42 Clendinnen 2003: 272.

43 Clendinnen 2003: 266-267.

44 Smith 2001: viii. 
Many of Bennelong's twentieth-century biographers have imagined him only loosely moored to Eora ways of being, ready to drift towards the British and their abundance of civilised riches. But it seems clear that if we historians and storytellers are to hazard a re-creation of his thoughts, we must first and foremost imagine him as Gerry Bostock has, for example: as an Eora man, remaining captive in the settlement longer than he needed to so that he could acquit the special responsibilities associated with that place, perhaps, because someone had to, 'to sing back the spirits of [the Gudjigal people] who died outside their country', even if he was not yet fully trained for the task. ${ }^{45}$

After his return from England, Bennelong appears to have reintegrated himself into Eora networks and patterns of life as they had adapted to the presence of the colony. ${ }^{46}$ As Isabel McBryde began to demonstrate as early as 1989, Bennelong's status remained high into the nineteenth century. Although his semi-official role as mediator had waned, he continued to command attention from 'persons of the first respectability', and maintained a purposeful pattern of movement between his Aboriginal community and the settlements at Sydney and Parramatta, trading, socialising, and participating in events and ceremonies. ${ }^{47}$ As Kenny had acknowledged in 1973, Bennelong's people continued to remember him with respect in the decades after his death. ${ }^{48}$

Grace Karskens recently asserted that: 'stories of Bennelong as the "first drunken Aborigine", shunned by women of both races, a man hopelessly and helplessly "caught in a void between two cultures" are myths'. ${ }^{49}$ So we must ask: why has tragedy remained the most appealing mode for biographers of Bennelong across the past 70 years, despite appealing alternatives, and in the face of mounting evidence that suggests other narratives? My answer to this question is that the veracity of Bennelong's tragedy is multi-layered; his story has never simply been a reflection of the available historical evidence. As well as interacting with the primary sources, the tragic version of Bennelong's story has maintained a mutually affirming relationship with a nest of notions about Aboriginal history and cross-cultural relations that have held continued claims to plausibility across the period, despite what have been understood as radical changes in the making of Australian history.

45 Bostock 1994: 613-618.

46 Smith 2009: 25-26. See also Smith 2006: 79-81.

47 McBryde 1989: 27-29. See also McBryde 2000.

48 Kenny 1973: 65-66.

49 And she asks: if the taken-for-granted failure of Bennelong is not true, is it perhaps necessary to rethink 'what happened to Aboriginal people in early Sydney', or even across the continent, as a whole? Karskens 2009: 422-424. Thomas Kenneally has also begun to question Bennelong's tragedy: in Commonwealth of Thieves he accepted the story of Bennelong's decline and alienation, but in Australians: Origins to Eureka he notes that Bennelong has often been used by European writers as an 'archetype of his people's tragedy', but that this may have more to do with 'attitude' than evidence. Kenneally 2005: 446, 2009: 219. 
Bennelong's tragedy is based in a particular interpretation of the best-known sources for his life. His tragedy reflects the 'shape' formed when the accounts of the First Fleet's diarists are combined with the acerbic Sydney Gazette report of his death. ${ }^{50}$ Together, the journal writers offer lively coverage of a succession of notable incidents involving Bennelong in the period 1789-1792; his kidnap and residence at Government House, his behaviour when Phillip is speared, the way his household on Bennelong Point functions, and so on. The excitement of the diarists as they observed the world of the Eora during this period is palpable. For Watkin Tench, in late 1790, 'our greatest source of entertainment now lay in cultivating the acquaintance of our new friends, the natives' ${ }^{51}$ If this closely engaged reportage gives an illusion of completeness, the relative sparseness of references to Bennelong after 1795 may give the impression he has fallen into an abyss. Storytellers generally assimilate, rather than reflect upon, this pattern. Bennelong's tragedy also relies on a fairly disingenuous reading of these sources. As Kate Fullagar observes in the present volume, European attitudes to the Eora were changing, and relations became more tense, as the settlement became more secure - the Eora and the British were no longer 'new friends' when Bennelong returned from England. We should surely be wary of adopting, as Brodsky does, for example, David Collins' frustration as he finds that Bennelong could have enjoyed a legitimate and comfortable place living with the Governor into the nineteenth century but threw this chance away. ${ }^{52}$ Keith Willey made a revealing half-circle of historical thinking in his 1979 book When the Sky Fell Down. He discussed 'The end of the Noble Savage', by which he meant the demise of Rousseau's ideal in the hearts and minds of the Sydney colonists. He found that Bennelong's 'rapid degeneration' contributed to the demise of the notional noble savage, but he did not come full-circle to ask whether its demise may, or may also, have shaped the way our sources report on Bennelong's behaviour. ${ }^{53}$

The written sources emanating from the colony itself, no matter how sensitive or enlightened we might find some of the diarists, are centred in European thought and at Sydney Cove. When the writers feel that Bennelong is drawing closer to them and their way of thinking, he appears to be safe in the bosom of civilisation. When he appears less often, the colonists feel he is drifting away from what Tench described as 'the comforts of a civilised system', back to 'a precarious subsistence among wilds and precipices' ${ }^{54}$ As Maria Monypenny has demonstrated in the Tasmanian context, the ongoing use of this pseudogeographic 'coming in' and 'going out' is thoroughly linked with the maintenance of a Eurocentric perspective. ${ }^{55}$ Manning Clark, for example, refers to Bennelong's

50 Sydney Gazette, 9 January 1813.

51 Tench 2009[1793]: 160.

52 Collins 1971[1802] II: 134; Brodsky 1973: 71. See also McBryde 1989: 27.

53 Willey 1979: 128.

54 Tench 2009[1793]: 108.

55 Monypenny 1995: 73. 
increasingly frequent 'absences from the Governor's house' on his return from England. ${ }^{56}$ These absences necessarily signify 'presences' somewhere else, but they are not presences that Clark is interested in imagining.

Few of Bennelong's modern biographers have been able to imagine him moving between the colony and Aboriginal life in a sustainable way. A play produced by Koories in Theatre in 1995 was exceptional in finding a positive metaphor for Bennelong's 'in-between' status: his story is intertwined with that of Ancestor Platypus, an animal with a 'multifaceted nature' like Bennelong's, that helps him find a niche in a rapidly changing world. ${ }^{57}$ Most storytellers are uneasy when Bennelong appears to be 'in limbo between two societies', ${ }^{58}$ and feel a need to send him one way or the other. Where Clark imagined Bennelong 'going out' of the settlement as part of a downward trajectory, an article in the National Aboriginal Day magazine of 1981 sought a happy ending, and proposed instead: 'Occasionally he went back to his tribe but his visit to England made him feel superior to other Aborigines and he always returned to his white friends in Sydney.'59 Tench had commented that Bennelong, coming and going from the settlement in late 1790, sometimes wore the clothes that he had been given, and sometimes he carried them in a bag around his neck. ${ }^{60} \mathrm{It}$ appears Bennelong dressed when it suited him and this left the colonists with an equivocal understanding of his place in the settlement. ${ }^{61}$ Our late twentiethcentury storytellers are much less willing to be equivocal. A children's book published in 1970 concludes its story as Bennelong sails for England, finding that Bennelong's period of captivity transformed him. He happily adopted English dress, food and the 'easy' life, and 'liked standing in the sunlight and looking at his shadow. His shadow was no longer that of Bennelong of the Cadigals. It was the shadow of a white man. ${ }^{62}$ More often, however, this will to a definite outcome results in Bennelong's fall. 'Swimming Monkey', a contributor to current web forum Everything2.com, uses Bennelong's state of undress to evoke despair and disgrace, saying:

As the years went by his drinking became progressively heavier and he ceased to trouble himself with dressing in the gentlemanly finery he had been so fond of earlier, instead becoming contented with slinking about in dishevelled [sic] rags. ${ }^{63}$

As Simon Schama has put it, to honour the 'obligations of tragedy ... we must proceed until all is known; a verdict declared; a sacrifice made ready; an

56 Clark 1962: 143.

57 Koories in Theatre 1995.

58 Sykes 1988.

59 'The Governor's friend', National Aboriginal Day Magazine 1981: 31.

60 Tench 2009: 108.

61 McBryde 2000: 253.

62 Endeavour Reading Programme 1970: 44. Dark had said something only slightly different, but with quite a different meaning: that dressed, Bennelong's shadow was the 'same as the shadow of a white man'. Dark 1980: 264-265.

63 Swimming Monkey 2007. 
atonement decreed'. ${ }^{64}$ Once dressed, the tragic Bennelong cannot again be undressed without being naked. Once he seems to have reached the peak of his career, storytellers are impatient to get rid of him. Clendinnen is not alone in feeling that Bennelong 'should have died earlier'. Manning Clark returned him from England to show 'other aborigines [sic] the benefits of civilisation' ${ }^{65}$ But only two pages later, Bennelong demonstrates the awful, ironic reality that 'the closer his contact with civilisation, the more the aborigine was degraded'. Far from being interested in further ups and downs in Bennelong's fortunes, Clark disposed of him there and then - indeed, 'headlong', as we have seen. ${ }^{66}$ The next time we meet Bennelong in Clark's history he is in his grave. ${ }^{67}$ A twenty-firstcentury biographer writes 'only eight years after [Bennelong's] return, he died an alcoholic', ${ }^{68}$ robbing him of ten years of life between 1795 and 1813. Perhaps this omission is part of a systematic 'misremembering' of Bennelong's latter years as well as an arithmetic mistake. ${ }^{69}$ As Karskens observes, storytellers have wilfully overlooked that 'Bennelong got his life back together' after facing an initial series of reversals on his return from England. ${ }^{70}$

Hayden White suggests that history is woven of two kinds of truth: 'correspondence' to the world, and 'coherence'. The latter is formed as the historian forges a comprehensible narrative from the chaotic and incomplete evidence left behind by the past, using the literary modes of romance, comedy, tragedy and satire. White encourages historians to recognise and deploy consciously the literary aspects of their work to draw out historical truths, but feels that many historians, and readers, instead conflate a history's shape with the shape of the past itself. ${ }^{71}$ One of the ongoing attractions of a tragic mode Bennelong's story is surely that it makes the evidence of Bennelong's life cohere into a compelling story, in which there is only one reversal of fortune for Bennelong - one which leads directly to his death.

Tragedy, of course, is a literary and dramatic form with a long history of practice and philosophy, in which some of the most complex and troubling characters of western cultural tradition have been created. Although a few of Bennelong's biographies have approached full scale dramatic treatments, Dark's and Brodsky's among them, most of the 'biographies' considered here are pocket-sized sketches, or cameo appearances in a broader story. An eclectic local production, tracing Aboriginal history from the Dreaming to the present, encapsulates Bennelong's life thus:

64 Schama 1991: 262.

65 Clark 1962: 143.

66 Clark 1962: 145.

67 Clark 1962: 346.

68 Flood 2006: 42.

69 Portelli 2003: 30.

70 Karskens 2009: 422.

71 White 1978: 122-123, 128-129. 
He was befriended and taken to England by Captain Arthur Phillip; treated as a curiosity; learned English quickly; attempted to reconcile the English and the Eora in the early days; became a victim of alcoholism; tragic life story - wafting from the white world to the black. ${ }^{72}$

This biography is cursory, by no means masterfully written, and probably has no direct relationship with the primary sources. Yet it manages to convey a powerful impression. The adjective 'tragic' functions as a flag; it signals agreement with other accounts of Bennelong's pitiable failure, and recruits the reader's prior knowledge of this failure. It relies partly on intertextual consensus, and gives the tragic wheel another spin as it does so. Even if the reader has no prior knowledge of him, the compact evocations of Bennelong's alcoholism, and his unsuccessful attempt to reconcile 'two worlds' provide ample explanation of an inevitable and partly self-destructive course towards alienation and despair. Importantly, the adjective 'tragic' gives a signal to the reader about how she should feel, a matter I will also revisit in what follows.

New versions of Bennelong's story are not born into a vacuum. As Hayden White argues, existing versions of stories, and points of consensus within the writing and reading community, exert considerable influence on the perceived possibilities for telling the story in the future - making some modes and explanations seem purely logical and others outlandish. ${ }^{73}$ Broader stories of Aboriginal decline and death have formed a constant background for the retelling of Bennelong's story across the twentieth century. In the late nineteenth century, tragedy was commonly invoked to express regret about the inevitable process of Aboriginal extinction, evincing ambivalence about the success of the pioneers in the certainty that it was 'too late', or impossible, to make amends. ${ }^{74}$ Histories of the early twentieth century expressed less regret, but no less certainty, Spence and Fox claiming in 1910, for example: 'it is possible to calculate with almost certainty a date on which "the last post" will be sounded over the Australian, as it has been over the Tasmanian aboriginal race' $\cdot{ }^{75}$ Although it was becoming patently clear in the post-war period that Aboriginal populations were maintaining themselves, or in fact increasing, as Charles Duguid sought to bring to Australians' attention, ${ }^{76}$ the narratives of fatal impact continued. Bruce Elder, in his anti-celebratory bicentennial history Blood on the Wattle, no doubt partly inspired by the Aboriginal renaissance of the 1970s, wrote:

The fatal moment when Phillip stepped ashore was the moment when the conflict began. There was no spear thrown; no musket fired. But the course of events was set upon its inexorable path. The two cultures were so different ... There was no possibility of compromise. One side respected

72 Ellis 2006: 113 .

73 White 1978: 128.

74 Foster, Hosking and Nettelbeck 2001: 26-28.

75 Spence and Fox 1982[1910]: 142.

76 Duguid 1963. 
the land; one side exploited the land. One side was basically peaceful and benign; the other was essentially sadistic and autocratic. One sought harmony; the other was driven by aggression and competitiveness. ${ }^{77}$

For Elder, Phillip's first footfall was to bring about the end of Eden. As Grace Karskens observes, 'in settler history we seem to be searching constantly for beginnings ... but in Aboriginal history of the colonial period so often the search is for endings' ${ }^{78}$ Likewise, Heather Goodall has observed the readiness with which stories of Aboriginal success have been erased from public memory in a 'politics of failure'.$^{79}$ Each new version of Bennelong's story has been born into a reciprocally affirmative relationship with powerful narratives of fateful Aboriginal decline, death, extinction and failure. His tragedy gives this largescale, impersonal movement of history a human face and, as a specific instance, apparently supported by historical evidence, contributes to the truth quotient of the larger tragedy. Thus Clendinnen casts Bennelong and Phillip as the leaders of two peoples, on whose shoulders the weight of history rested, and finds that 'each failed, to their own and their people's injury, and to ours' ${ }^{80}$ She means that Phillip and Bennelong had the best chance of setting up enduring good relations between European colonists and Indigenous Australians, and that they failed, instead setting a course through uncertainty, conflict and mutual disrespect across the continent. This grand narrative makes me uneasy: if Bennelong's story can provide an answer to our questions about what went wrong, right back there at Australia's beginning, how can we remain receptive to stories of Aboriginal survival and regeneration across the following two centuries? And how can we truly appreciate the diverse and ongoing impacts on Aboriginal communities of the Queensland Native Police patrols of the 1860s, or government policy of the 1920s?

Bennelong's tragedy is emphatically a cultural tragedy, played out on the beaches where Manning Clark's 'barbarism' meets 'civilisation'. ${ }^{81}$ The momentum of the British Empire, and its history of progress, sets these two cultural continents on a collision course. To generations of white historians, like Bruce Elder above, it has seemed inevitable that the 'weaker' Indigenous culture would come off worse. The collision might easily crush anyone standing near the edge. As it is economically put on the 'Creative Spirits' website, 'Bennelong got caught between the two worlds and he died as a lonely alcoholic with a broken spirit in 1813'. ${ }^{82}$ In Brodsky's biography, Bennelong was desired by the British to be 'the bridge between 18th century civilisation and the Stone Age'. But this bridge was badly built, 'the foundations were always shaky, the bridging material

77 Elder 1988: 11

78 Karskens 2009: 422.

79 Goodall 1987: 27-31.

80 Clendinnen 2003: 286.

81 Clark perceived a 'terrible sense of doom and disaster which pervaded the air whenever the European occupied the land of a primitive people. For the culture, the way of life of the aborigine [sic] was doomed' as soon as the British set eyes on their land. Clark 1962: 3-4, 110.

82 Korff 2009. Creative Spirits is a web design company that sponsors a number of websites encouraging Australians to learn about Aboriginal history, culture and art. 
human, and the mode and motivation of construction ever suspect' ${ }^{83}$ Here, all that was necessary for Bennelong's 'fall' was gravity, the bridge faltered and he plunged into the void commonly understood to lie between these two cultural islands. ${ }^{84}$ Eleanor Dark had located the destructive force of colonisation within the souls of her Aboriginal characters. They are a 'timeless' people confronting 'change', which comes upon them like a spiritual poison, creating a 'division in their own hearts'. One of her elders, Tirrawuul, dies because he cannot 'endure even the first faint forewarning shadow of change' to a life governed by a 'faith which never had been challenged' ${ }^{85}$ Dark's Bennelong is singled out as a man in particular danger. His fellow captive, Colbee, managed to remain aloof, resolved not to engage with the captors beyond a watchful compliance. Colbee thus remains 'whole' while Bennelong is torn by an internal 'strife', as part of him is drawn towards the white men and the possibility of becoming like them. ${ }^{86}$

This is a familiar story: a fascination with self-destructive cultural transgressions has deeply penetrated the western literary and popular imagination. The archetype is perhaps Joseph Conrad's character Kurtz in his 1899 novella Heart of Darkness. Kurtz's domination of his African workers has transcended duty and come to dominate his own identity - he is re-shaped into their cultural image. Kurtz has lost his senses, and his colleagues are at once fascinated and appalled. ${ }^{87}$ A not dissimilar imaginary drives Peter Goldsworthy's 2003 novel Three Dog Night. Grown up Adelaide private school boy, Felix, goes to the 'Centre' as a doctor, and returns initiated as a Warlpiri man, abrasive, discontented, and terminally ill. ${ }^{88}$

Following Mary Douglas' theorisation of cultural purity and pollution, Bennelong's willing pastiche of dress, manners and language, seems to offend 'cleanliness' and invite danger. His ingestion of British substances, like alcohol, and ideas, at once sees him absorbed into the British cultural and political body, and signals the contamination of the Aboriginal body via Bennelong's mouth. ${ }^{89}$ For Clark, Kenny, Stanner and Mulvaney, as illustrated above, Bennelong's story showed what would happen to Aboriginal people when exposed to 'civilisation', recycling, with different inflections, the nineteenth century theory of 'degeneration', which held that a race could actually fall downwards on the evolutionary ladder (or off the bottom of it) through unhealthy living. ${ }^{90}$ As Douglas suggests, the belief that pollution weakens is closely followed by a suspicion that only those who are weak or careless would fail to resist pollution. ${ }^{91} \mathrm{JJ}$ Healy, writing for a popular audience in 1977, made the charge that this process was self-destructive almost explicit, finding 'continuity between

\footnotetext{
83 Brodsky 1973: 41.

84 Karskens 2009: 424.

85 Dark 1980: 177, 179-180.

86 Dark 1980: 264-265. See also Clendinnen 2003: 268.

87 Conrad 1991[1899].

88 Goldsworthy 2003.

89 Douglas 2002: 4-5, 142.

90 Stern 2005: 14.

91 Douglas 2002[1966]: 4-5, 142.
} 
Bennelong and those Aborigines who would speed the dissolution of their own societies by a self-generated fascination with the artefacts of European society' ${ }^{92}$ Over the past 20 years or so, the use of Bennelong's story to imply that Aboriginal people's 'problems' are self-inflicted has perhaps become less explicit. But in the ongoing narration of Bennelong's story as a cultural and an alcoholic tragedy, the implication that transculturation is analogous to a shameful cultural addiction persists. In the Barani Indigenous History pages of the Sydney City Council website, a disavowal of Bennelong's adoption of 'European dress and ways' is paired with an acknowledgment of his importance: 'While Bennelong suffered from the worst aspects of enculturation, he also represents those who tried to change the behaviour of Europeans on Aboriginal lands. ${ }^{93}$ It is as if a cleansing of his memory is required.

Bernard Smith, in his Boyer Lectures of 1980, characterised Bennelong as a man who had tried to function on both sides of the cultural divide, a 'game' which has 'always been an emotionally difficult one to play; its benefits precarious. Most became alcoholics' ${ }^{94}$ Smith accorded Bennelong a legacy, passed down a line of 'fool kings' and 'clowns', to, among others, Albert Namatjira:

Life between the two cultures has always been fraught with these terrible tensions. Take the case of Namatjira ... His tragic end is well known. In sharing liquor to which he was legally entitled with others of his tribe who were not, he was caught between the laws and customs of two societies. His trial and death shortly afterwards are now a part of the history of both cultures. ${ }^{95}$

Like Bennelong's, Namatjira's is a life contaminated by that vice of the Europeans, alcohol, and overstretched to breaking point by the embrace of two worlds. Smith felt that unlike the heroic resistance leaders, Pemulwuy, Yagan and their ilk, these 'Quislings' or 'Jacky Jackies' have 'always been regarded by Aborigines with suspicion' ${ }^{96}$ Their ambiguous, vulnerable and tainted condition is super-historical in Smith's account. It is not the product of oppression, for example, in Namatjira's own time. Rather, as Smith insists through repetition, it has 'always been'. Indeed, Smith's logic suggests that to be colonised will always carry the risk of being divided, weakened. Ian Anderson finds this motif of internal division a constant refrain within his own discipline, and replies: 'personhood is had through coherent experience ... The separation of black bit, white bit is a denial of humanity'. ${ }^{97}$ Another reply comes from a contributor to the First Australians guestbook on the SBS website, introducing herself as a

92 Healy 1977: 32.

93 Heiss 2002.

94 Smith 1980: 37.

95 Smith 1980: 38-39.

96 Smith 1980: 37.

97 Anderson 2003: 51. See also Birch 1993, 'You see me/ half Black/ half white/ but never whole'. 
Wardandi Bibbulmun woman: 'Bennelong was an inspiration, a man who spoke the wadjela ways, but whose heart belonged to his people. We have all learnt to walk the wadjela walk, but remain embedded in our culture' ${ }^{98}$

Alcohol is a key ingredient in the story of Bennelong's failure. Twentiethcentury biographers have reached for the bottle without hesitation, finding as a recent children's book does, that Bennelong drank 'to ease the pain of loneliness and confusion', ${ }^{99}$ or that it was alcohol itself that precipitated his alienation - a foreboding musical squall broke out as the first draught flowed down Bennelong/ Caliban's throat in a 2001 reinterpretation of Shakespeare's The Tempest as a reconciliation story. ${ }^{100}$ But alcohol is by no means a historiographically neutral substance. The first-hand accounts depict Bennelong engaging in both 'good' and 'bad' drinking, with Tench's admiring comment that he could hold his grog like any gentleman ${ }^{101}$ contrasting with the vulgar and insolent 'propensity to drunkenness' cited by the report of his death in the Sydney Gazette. ${ }^{102}$ These two comments were made at opposite ends of Bennelong's association with the British, certainly, but they were also thoroughly bound up with ideas surrounding social class, morality and alcohol at a time when, as Stephen Garton argues, the British were attempting to wrest Aboriginal peoples' wealth from them and fit them into colonial society and economy - right at the bottom. ${ }^{103}$ When Bennelong ceased to drink exclusively with the officers, their interpretations of his drinking became more closely aligned with attitudes towards the lower classes, who took 'unruly' pleasure in bloodsports and drinking to excess. ${ }^{104}$ Neither does the symbolic valency of alcohol diminish as we approach the present. The social understandings surrounding alcohol abuse in contemporary Australian society are so rich that there is room in Bennelong's story for everything from pity, as in Melinda Hinkson's 'lonely alcoholic with a broken spirit', 105 to the smutty humour of Keith Willey's comment: 'The nature of [Bennelong's] association with the brewer, James Squire - apart from a notable liking for his product - is not known'. ${ }^{106}$ When Mulvaney, among others, finds that Bennelong's drinking reflects a lack of steadiness of character, and an inability to discriminate between good and bad parts of British culture, he projects onto Bennelong eighteenth-century ideas of classed morality, but also finds a readily comprehending audience in the present. ${ }^{107}$ As Marcia Langton has demonstrated, alcohol has long played a part in the popular and official representation of Aboriginal communities. Langton sees Bennelong as the first

\footnotetext{
98 SBS Website: Trish Hill-Wall, 21 October 2008, 18:18hrs.

99 Sheppard 2005: 27.

100 Tweg 2004: 50.

101 Tench 1961[1793]: 159-160.

102 Sydney Gazette, 9 January 1813.

103 Garton 1990: 9-15, 19-20, 36. See also Reynolds 1983: 124-133.

104 Karskens 2009: 128.

105 Hinkson 2001: 7.

106 Willey 1979: 146.

107 Mulvaney contrasts the way in which Arabanoo, while he savoured bread and tea, 'resisted alcoholic drinks with "disgust and abhorrence", according to the approving Tench, but his successor, Bennelong, succumbed to grog'; Mulvaney 1985: 13. See also Clendinnen 2003: 275.
} 
'drunken Aborigine', transformed by the alcohol that was pressed on him by the colonists, and then depicted as a 'degenerate native' lacking the restraint and dignity necessary for civilisation. She finds that, from Bennelong's lifetime, the image of the 'drunken Aborigine' has sustained its own momentum. ${ }^{108}$ Indeed, I believe that the association of Bennelong's fall with alcohol has helped to sustain this story of tragedy across the latter part of the twentieth century and into the twenty-first.

\section{III}

There is one last kind of truth I would like to consider in closing. American scholar of public memory Vivian Bradford proposes a path of moral relativism through the maze of public historiography. He is happy to acknowledge a diversity of historical expression and eschew the notion that any one version has a monopoly on transcendent truth, but reserves the right to measure public memories 'by the quality of the social relationships established or sustained through their expression'. ${ }^{109}$ Tragedy stakes a claim to be morally elevating. Bernard Smith's larger purpose in his Boyer Lectures was to call on Australian writers to engage with the tragic muse 'an old Aboriginal woman, surviving precariously as a fringe dweller', a muse that white Australians had thus far preferred to forget. ${ }^{110}$ He argued that engagement with the tragedy of Aboriginal history would spur the 'concerned conscience' to agitate for improvement of legal, health and education outcomes for contemporary Aboriginal Australians. ${ }^{111}$ For tragedy to have the transformative power that it was renowned for in the Greek polis, however, it needs to present a noble hero, felled by a weighty dilemma which shakes the audience's own sense of self and society. ${ }^{112}$ Bennelong's tragedies are for the most part too easy on the concerned conscience, embedded as they are in comfortable old narratives affirming European superiority, Aboriginal fragility and the role of the caring person in saving the Aborigine from himself. Bennelong, understood as a politically and culturally compromised drunkard to the last, fails to take responsibility for his fate as a hero ought. He fails to regain the respect of the audience as Othello did, for example, when come to his senses at last, he asks of Lodovico 'Speak of me as I am ... of one that loved not wisely but too well'. Too many of Bennelong's tragedies allow the concerned conscience to confuse tragedy with 'inevitable misfortune', as it had been in the nineteenth-

\footnotetext{
108 Langton 1993: 195-206.

109 Bradford 1997: 205.

110 Smith meditates 'at times it would seem as if all the culture of old Europe were being brought to bear upon our writers and artists in order to blot from their memories the crimes perpetrated on Australia's first inhabitants'. It does not occur to him that the unreflective use of this cultural armoury in the service of remembering these crimes might provide us with only a partial and highly problematic view of the past. Smith 1980: 16, 22-23.

111 Smith 1980: 31, 34.

112 Muldoon 2005: 248.
} 
century tragedies of Aboriginal extinction, handing out easy absolution to its audience. ${ }^{113}$ As outgoing Aboriginal and Torres Strait Islander Social Justice Commissioner Tom Calma recently observed:

The Australian community had become so accustomed to stories of Indigenous disadvantage that they had become immune to it, and ... have come to believe that this situation is intractable, ... and for some people, the fault of Indigenous peoples themselves ... So while I firmly believe that these stories of disadvantage and dysfunction should be told, I also believe that they should not be told just for the sake of it. ${ }^{114}$

Re-telling Bennelong's story in the present as an allegory for Indigenous failure is gratuitous. However well-intentioned, it can end up simply indulging the 'industrial deafness' of non-Indigenous Australians. ${ }^{115}$ More than this, the audience might feel absolved by Bennelong's comprehensive failure, and social and spiritual obliteration. His 'Christ-like suffering', as Andrew Lattas has put it, may 'restore settler Australians to a lost moral order', without any efforts towards justice in the present. ${ }^{116}$

The 'concerned conscience' has gone on to become a major force in Australian history making and politics since Bernard Smith evoked it in 1980, being heavily involved in Reconciliation and in the final ousting of John Howard for a new Prime Minister who would make an apology to the Stolen Generations within a few months of his election. Since the 1970s, the retelling of Bennelong's story as a tragedy has perhaps reflected a disaster that continues to unfold for the concerned conscience in the present: a realisation of the continued culpability of non-Indigenous Australians in the destruction of Aboriginal lives, lifeways, culture and society. Lamentations about the long-dead Bennelong's fall into disgrace, and the irreversible rupture in cross-cultural relations that this is held to signify, provide an easy target for accusations of 'conspicuous compassion', a cheap expenditure of tears and talk, taking the place of 'sensible action'. ${ }^{117}$ Renewed conservative claims on Australian history have seen the Bennelong Society, a conservative think-tank on Aboriginal policy founded in 2001, adopt Bennelong as a poster boy for assimilation. The Society's Bennelong readily perceived the 'benefits' of the British lifestyle; devised, with Phillip, the 'peaceful coming-in of the Eora'; and is deemed to have succeeded in British terms, as the Society would like Aboriginal people to do in the present and future. ${ }^{118}$ The Society dissociates itself from Bennelong's latter years, his retirement from public life, explaining on its website that Bennelong's drinking problem began during his time in England. ${ }^{119}$ This Bennelong represents a self-conscious response to the down-beat, dead-end of Bennelong's tragedy. It is in the interests of the

113 Muldoon 2005: 245.

114 Calma 2008.

115 Calma 2008.

116 Andrew Lattas 1990, cited in Broome 1996: 71.

117 Mason 2005: 6.

118 Dissel nd. See also Johns 2000.

119 Dissel nd. 
Society and its supporters to hold a monopoly on 'sensible', constructive action, the solution to the 'Aboriginal problem', which those who have promoted selfdetermination have only further compounded. ${ }^{120}$ The Society's no-nonsense goahead Bennelong endorses Aboriginal participation in the mainstream capitalist economy, leaving soft questions about culture and history, loss, shame and responsibility behind.

The telling of Bennelong's tragedy in the years following the 'History Wars' might be read as a re-assertion of the relevance of mutual grieving, apology, atonement and the need for reconciliation on a number of levels, not only the 'practical' level offered by the Bennelong Society. The recent television series First Australians aired various interpretations of Bennelong's life. Peter Read's Bennelong, for example, 'goes out' of Sydney Cove in his later years because he has seen all that Europeans have to offer, in a situation of relative equality. He ultimately rejects it, choosing his own life. Inga Clendinnen had the last word on Bennelong, though, saying 'to see that light-footed man, that man of so much political skill and resilience so reduced is, I think, tragic' ${ }^{121}$ In the book which accompanied the series, Marcia Langton closely followed Clendinnen's interpretation, giving Bennelong a central place in the 'dance' with the colonists. When Bennelong returned from England he was:

left to survive in the profoundly changed circumstances of his country. He had changed, too, not least because of his alliance with Phillip. At the end of his days, his mood of increasing bitterness and alcoholic decline reduced him from his warrior's countenance to a weak, defeated man. ${ }^{122}$

In First Australians, Bennelong's story appears among many stories, of hope, friendship, massacre and cruel institutions, death and pain, survival and celebration across the continent, and across more than two centuries. Why should not two of our foremost public thinkers come together around Bennelong's story to grieve for generations of talented Aboriginal men cut off by war, incarceration, accident and suicide?

The fabric of Bennelong's tragedy is a closely woven web of veracities; historical, allegorical, literary and moral. The threads are not easy to disentangle, but in the light of a body of evidence for the varied fortunes and strong relationships of Bennelong's last 18 years, it is clear that we must reflect further on his story and on its uses. Tragedy is not life, or history, but a dramatic or literary genre with its own logic and genealogy. If Bennelong's life is 'tragic', then it is storytellers who have made it so.

120 'Nugget Coombs revisited', Counterpoint, 23 April 2007.

121 Perkins and Nowra 2008.

122 Perkins and Langton 2008: 29. 


\section{References}

Benelong Bugle (J Parks, Sydney Opera House Site, Sydney)

National Aboriginal Day Magazine

Sydney Gazette

Anderson, Ian 2003, 'Black bit, white bit', in Blacklines: ContemporaryCcritical Writing by Indigenous Australians, Michele Grossman (ed), Melbourne University Press, Carlton, Victoria.

Attwood, Bain 1996, 'The past as future: Aborigines, Australia and the (dis) course of history', in In the Age of Mabo: History, Aborigines and Australia, Bain Attwood (ed), Allen and Unwin, St Leonards, NSW.

Birch, Tony 1993, 'Half caste', Australian Historical Studies 25(100): 458.

Bostock, Gerry 1994, 'Colebe', Meanjin 53(4), Summer: 613-618.

Bradford, Vivian 1997, “"A Timeless Now”: memory and repetition', in Framing Public Memory, Phillips (ed), University of Alabama Press, Tuscaloosa.

Brodsky, Isadore 1973, Bennelong Profile: Dreamtime Reveries of a Native of Sydney Cove, University Co-Operative Bookshop Limited, Sydney.

Brooks, Barbara with Judith Clark 1998, Eleanor Dark: A Writer's Life, Macmillan, Sydney.

Broome, Richard 1996, 'Historians, Aborigines and Australia: writing the national past', in In the Age of Mabo, Bain Attwood (ed), Allen \& Unwin, St Leonards, NSW.

Calma, Tom 2008, 'Essentials for social justice', 'Reform' speech, delivered 20 February 2008, Australian Human Rights Commission, updated 3 February 2009, viewed 17 February 2009, <http://www.hreoc.gov.au/about/media/ speeches/social_justice/2008/essentials_reform20080220.html>

Clark, Manning 1962, History of Australia, vol 1, Melbourne University Press, Melbourne.

Clendinnen, Inga 2003, Dancing with Strangers, Text Publishing, Melbourne.

Collins, David 1971[1798-1802], An account of the English colony in New South Wales: with remarks on the dispositions, customs, manners, Ec. of the native inhabitants of that country, to which are added, some particulars of New Zealand, Libraries Board of South Australia, Adelaide.

Commonwealth of Australia 2006, 'Sydney Opera House: Nomination by the Government of Australia of the Sydney Opera House for Inscription on the World Heritage List 2006', prepared by the Australian Government and 
the New South Wales Government, viewed 20 February 2009: <http:/ /www. sydneyoperahouse.com/uploadedFiles/About_Us/Ad_Hoc_Information_ Pages/WorldHeritageNominationDocument.pdf>

Conrads, Joseph 1991[1899], The Heart of Darkness, Penguin Books, London.

Curthoys, Ann 2000, 'Mythologies', in The Australian Legend and its Discontents, Richard Nile (ed), University of Queensland Press, St Lucia, Queensland.

- and John Docker 2006, Is History Fiction?, University of New South Wales Press, Sydney.

Dark, Eleanor 1980[1941], The Timeless Land, Fontana Books, Melbourne.

- 2002[1941], The Timeless Land, Harper Collins, Pymble, NSW.

Dissel, Dirk van, 'Woollawarre Bennelong, the Bush Politician (1789 - 1792)', The Bennelong Society, viewed 17 February 2009: <http:/ / www.bennelong.com.au/ articles/bennelongbio.php>

Douglas, Mary 2002[1966], Purity and Danger: An Analysis of the Concepts of Pollution and Taboo, Routledge, London.

Duguid, Charles 1963, No Dying Race, Rigby, Adelaide.

Egan, Ted 1987, The Aboriginals Songbook, Greenhouse Publications, Richmond, Victoria.

Elder, Bruce 1988, Blood on the Wattle: Massacres and Maltreatment of Aboriginal Australians since 1788, Child \& Associates, Frenchs Forest, NSW.

Ellis, Jean 2006, Aboriginal Australians - Their Journey, Kaliarna Productions, Penrith, NSW.

Endeavour Reading Programme 1970, Bennelong, The Jacaranda Press, Milton, Queensland.

Flood, Josephine 2006, The Original Australians: Story of the Aboriginal People, Allen \& Unwin, Crows Nest, NSW.

Foster, Robert, Rick Hosking and Amanda Nettelbeck 2001, Fatal Collisions: The South Australian Frontier and the Violence of Memory, Wakefield Press, Kent Town, South Australia.

Goldsworthy, Peter 2003, Three Dog Night, Viking, Camberwell, Victoria.

Goodall, Heather 1987, 'Aboriginal history and the politics of information control', Oral History Association of Australia 9: 17-33.

Garton, Stephen 1990, Out of Luck: Poor Australians and Social Welfare, 1788-1988, Allen \& Unwin, Sydney. 
Healy, Chris 2002, 'History, culture and media magic', Australian Historical Studies 33(118): 121-126.

Healy, JJ 1977, 'A most tragic theme', Hemisphere 21(5): 28-32.

Heiss, Anita 2002, 'Barani' - City of Sydney Online Resource, viewed 8 August 2009: <http:/ / www.cityofsydney.nsw.gov.au/barani/themes/theme7.htm>

Hinkson, Melinda 2001, Aboriginal Sydney: A Guide to Important Places of the Past and Present, Aboriginal Studies Press, Canberra.

Johns, Gary 2000, 'The failure of Aboriginal separatism', presented to the Workshop 2000: Aboriginal Policy: Failure, Reappraisal and Reform, The Bennelong Society, viewed 17 February 2009: <http:/ / www.bennelong.com.au/ conferences/pdf/Johns2000.pdf>

Karskens, Grace 1990, The Colony, Allen and Unwin, Crows Nest, NSW.

Keneally, Thomas 2005, The Commonwealth of Thieves: The Sydney Experiment, Random House, Sydney.

- 2009, Australians: Origins to Eureka, Allen and Unwin, Crows Nest, NSW.

Kenny, John 1973, Bennelong: First Notable Aboriginal, Royal Australian Historical Society, Sydney.

Koories in Theatre with Pauline McLeod and Malcolm Mitchell 1995, 'Moobbajia: speak an unknown language: the English language through Koori eyes', Museum of Sydney, Sydney, flyer held at the AIATSIS Library, Canberra.

Korff, Jens-Uwe, 'Bennelong Point', Creative Spirits, viewed 16 March 2009: <http://www.creativespirits.info/oznsw/sydney/sitescbd/operahouse.html>

Langton, Marcia 1993, 'Rum, seduction and death: 'aboriginality' and alcohol', Oceania 63(3): 195-206.

McBryde, Isabel 1989, Guests of the Governor: Aboriginal Residents of the First Government House, Friends of First Government House Site, Sydney.

- 2000, "Barter ... immediately commenced to the satisfaction of both parties": cross-cultural exchange at Port Jackson 1788-1828', in The Archaeology of Difference: Negotiating Cross-cultural Engagements in Oceania, Robin Torrence and Anne Clarke (eds), Routledge, London: 238-277.

McGuanne, John 1901, 'Bennelong Point at Fort Macquarie', Royal Australian Historical Society Journal Proceedings 1(2).

Marrickville Council, 'Cadigal Whangal', viewed 20 February 2009: <http:// www.marrickville.nsw.gov.au/cadigalwangal/vegetation/bennelong.htm>

Mason, Brett 2005, 'The tragedy of conspicuous compassion', Party Room 1, Winter: 6. 
Monypenny, Maria 1996, "'Going out and coming in": cooperation and collaboration between Aborigines and Europeans in early Tasmania', Tasmanian Historical Studies 5(1): 64-75.

Muldoon, Paul 2005, 'Thinking responsibility differently: reconciliation and the tragedy of colonisation', Journal of Intercultural Studies 26(3): 245.

Mulvaney, Derek John 1985, A Good Foundation: Reflections on the Heritage of the First Government House, Australian Heritage Commission Special Australian Heritage Publication Series No. 5, Australian Government Publishing Service, Canberra.

‘Nugget Coombs revisited', Counterpoint, aired 23 April 2007, ABC Radio.

Perkins, Rachel and Marcia Langton 2008, First Australians: An Illustrated History, Melbourne University Publishing, Carlton, Victoria.

- and Louis Nowra 2008, First Australians, Blackfella Films and Special Broadcasting Service Corporation, Episode One, broadcast Sunday 12 October 2008.

Perkins, Charles 1988, 'Political Objectives', in The Australian People. An Encyclopaedia of the Nation, Its People and Their Origins, James Jupp (ed), Angus and Robertson, North Ryde, NSW.

Portelli, Alessandro 2003, 'The massacre at the Fosse Ardeatine: history, myth, ritual and symbol', in Contested Pasts: The Politics of Memory, Katharine Hodgkin and Susannah Radstone (eds), Routledge, London: 29-41.

Reece, Bob 1987, 'Inventing Aborigines', Aboriginal History 11(1): 16-17.

Reynolds, Henry 1983, 'Aborigines and European social hierarchy', Aboriginal History 7: 124-33.

- 2005, Nowhere People, Penguin, Camberwell, Victoria.

Ryan, Lyndall 1997, 'The struggle for Trukanini 1830-1997', Tasmanian Historical Research Association Papers and Proceedings 44(3): 153-173.

Schama, Simon 1991, Dead Certainties (Unwarranted Speculations), Alfred A. Knopf, New York.

Sheppard, Barrie 2005, The Life of Bennelong: Living in Two Cultures, Echidna Books Carlton, Victoria.

Smith, Bernard 1980, 'The spectre of Truganini', Boyer Lectures, Australian Broadcasting Commission, Sydney.

Smith, Keith 2001, Bennelong: The coming in of the Eora, Sydney Cove 1788-1792, Kangaroo Press, East Roseville, NSW. 
- 2006, 'Bennelong: ambassador of the Eora Part II', Australian Heritage, Autumn: 79-81.

- Wallumedegal. An Aboriginal History of Ryde, City of Ryde, updated 15th February 2009, viewed 15 February 2009: <http:/ / www.ryde.nsw.gov.au/WEB/ SITE/RESOURCES/DOCUMENTS/Information/wallumedegal.pdf>

Spence, Percy and Frank Fox 1982[1910], Australia, Vantage House, Cheltenham, Victoria.

Stanner, WEH 1968, 'After the Dreaming', Boyer Lectures, Australian Broadcasting Commission, Sydney.

- 1977, 'The history of indifference thus begins', Aboriginal History 1: 2-26.

Stern, Alexandra 2005, Eugenic Nation: Faults and Frontiers of Better Breeding in Modern America, University of California Press, Berkeley, California.

Swimming Monkey, 'Bennelong', 19th December 2007, Everything2, The Everything Development Company, viewed 17 March 2009: <http://www. everything2.com/index.pl?node_id=1922328>

Sykes, Jill 1988, 'Bennelong makes a point', Sydney Morning Herald, 8 October 1988: 81.

Tench, Watkin 1961[1793], Sydney's first four years: being a reprint of A narrative of the expedition to Botany Bay and A complete account of the settlement at Port Jackson, Angus and Robertson, Sydney.

- 2009[1793], A Complete Account of the Settlement at Port Jackson, Text Publishing, Melbourne.

Tweg, Sue 2004, 'Dream On: A “Reconciliation” Tempest in 2001', Contemporary Theatre Review 14(3): 45-52.

White, Hayden 1978, Tropics of Discourse: Essays in Cultural Criticism, The Johns Hopkins University Press, Baltimore.

Wikipedia, 'Bennelong', updated 26 January 2009, viewed 20 February 2009: <http://en.wikipedia.org/wiki/Bennelong>

Willey, Keith 1979, When the Sky Fell Down. The Destruction of the Tribes of the Sydney Region 1788-1850s, Collins, Sydney.

Willmot, Eric 1987, Pemulwuy: The Rainbow Warrior, Bantam Books, Sydney.

Wyndham, Marivic 2007, A World Proof Life: Eleanor Dark, a Writer in Her Times, 1901-1985, UTSePress, Sydney.

Ziegler, Oswald L 1974, Sydney Has an Opera House, Ambascol Press, Artarmon, NSW. 